\title{
The expression of HMGB1 and the receptor for advanced glycation end products (RAGE) in epithelial ovarian
} cancer

\author{
Jiheum Paek ${ }^{1,2 *}$ and Young Tae $\mathrm{Kim}^{3}$ \\ ${ }^{1}$ Gynecologic Cancer Center, Department of Obstetrics and Gynecology, Ajou University School of Medicine, Korea \\ ${ }^{2}$ Department of Obstetrics and Gynecology, Yonsei University Graduate School, Korea \\ ${ }^{3}$ Institute of Women's Life Medical Science, Department of Obstetrics and Gynecology, Yonsei University College of Medicine, Korea
}

\begin{abstract}
The aim of this study was to confirm the expression of high mobility group box 1 (HMGB1) and its receptor for advanced glycation end products (RAGE) in patients with epithelial ovarian cancer (EOC). A total of 78 patients with EOC comprised our cohort. They received debulking surgery followed by taxane and platinum chemotherapy. The mRNA levels of HMGB1 and RAGE in ovarian tissues obtained from surgery were detected using reverse transcription-PCR. In addition, the serum levels of HMGB1 were evaluated between cancer and non-cancer group. The mRNA levels of HMGB1 were higher in EOC compared to the non-cancer cohort (0.94 vs. 0.90) and there was no statistically significant difference. Similarly, the mRNA levels of RAGE did not differ between the EOC and non-cancer cohort. The serum HMGB1 levels were not greater in the cancer cohort than the non-cancer cohort $(0.40$ vs. $0.45 \mathrm{ng} / \mathrm{mL}, \mathrm{P}=0.106)$. Contrary to expectations as a promising biomarker for EOC, the expression of both HMGB1 and RAGE did not show significant differences in EOC group. Further studies are needed to assess potential roles in EOC.
\end{abstract}

\section{Introduction}

Epithelial ovarian cancer (EOC) is the fourth most common cause of cancer-related death in women worldwide, accounting for approximately $3 \%$ of all new cancer patients in 2009 [1]. Unfortunately, most of the patients are diagnosed with an advanced stage of EOC. Currently, there is no proven effective method for early detection in EOC and only the serum CA125 level has been used to predict the presence of cancer. However, its utility as a screening marker is limited due to its low sensitivity and specificity [2]. Moreover, the serum level of CA125 can be elevated in other cancers such as uterine cancer, gastrointestinal cancer, as well as in benign disease [3].

In order to increase the sensitivity and specificity for the detection of EOC, a number of novel markers have been investigated, including matrix metalloproteinase-1, osteopontin, and human epididimis 4 [46]. Of these, high mobility group box 1 (HMGB1) was characterized as a non-histone, nuclear DNA-binding protein [7]. The constant release of HMGB1, which functions as a proinflammatory cytokine, from necrotic tumor cells creates a microenvironment similar to chronic inflammation, a condition known to contribute to the development of epithelial malignancies, particularly inflammation-associated cancer [8]. Extracellular HMGB1 induces cancer cell growth, mobility, invasion, and metastasis via binding to specific membrane receptors including the receptor for advanced glycation end products (RAGE) [9]. RAGE, a multi-ligand member of the immunoglobulin superfamily of cell surface molecules, interacts with distinct molecules implicated in homeostasis, development, and inflammation [10-12]. A lot of studies have already investigated the overexpression of HMGB1 in different cancers, including breast, gastrointestinal, prostate, and pancreatic cancer [13-17]; measuring mRNA levels and HMGB1 would be promising as a biomarker in various cancers. In this study, we examined whether the expression of mRNA HMGB1 and RAGE were associated with the development of EOC and evaluated the correlation of the serum HMGB1 level and EOC.

\section{Materials and methods}

\section{Patients}

A total of 78 women who underwent surgery for a pelvic mass from May 2009 to February 2011 were included in this study. Their blood samples were collected before they received surgery and their ovarian tissues were selectively sampled during the operation. All surgical tissues were examined by a gynecologic pathologist and final surgical pathology reports were obtained and recorded. The chemotherapy regimen was 6 cycles of paclitaxel $175 \mathrm{mg} / \mathrm{m}^{2}$ and carboplatin at the area under curve of 5 . The baseline patient characteristics included patient age, body mass index, performance status, tumor stage, and tumor grade. Performance status was defined according to Gynecologic Oncology Group criteria as: $0=$ normal activity; $1=$ symptomatic, fully ambulatory; 2 = symptomatic, in bed less than $50 \%$ of the time. Written informed consent was obtained from all patients prior to collection of blood and surgery. This research was approved by the Institutional Review Board of Yonsei University Health System.

Correspondence to: Jiheum Paek, M.D, Gynecologic Cancer Center, Department of Obstetrics and Gynecology, Ajou University School of Medicine, Suwon, 164 World Cup-ro, Yeongtong-gu, Suwon 16499, Korea, Tel: +82- 31-219-5253, Fax: +82-31-219-5245, E-mail: paek.md@gmail.com

key words: HMGB1, RAGE, epithelial ovarian cancer

Received: March 10, 2017; Accepted: March 30, 2017; Published: April 03, 2017 


\section{Expression of mRNA levels of HMGB1 and RAGE}

For DNA and protein extraction, fresh ovarian tumors and normal ovarian tissues were obtained immediately after surgical excision and were stored at $-70^{\circ} \mathrm{C}$ before use. Total RNA was extracted from tissues using the easy-spin ${ }^{\mathrm{TM}}$ (DNA free) Total RNA Extraction Kit (Intron Biotechnology, Seongnam, Korea) according to the manufacturer's instructions. As a control reaction for intact RNA and cDNA, PCR amplification of the housekeeping gene $\beta$-actin was performed on all samples to normalize the sample amount. Amplification was performed for a predetermined optimal number of cycles. The PCR products were separated by electrophoresis on $1.8 \%$ agarose gels, which were stained with $0.5 \mathrm{mg} / \mathrm{mL}$ ethidium bromide. Quantification of proteins was performed by using a laser densitometer and analysis software (IMAGE READER LAS-1000 lite, Fuji Photo Film Co., Ltd., Tokyo, Japan) referring to the standard series. The densitometric integral derived from each sample band, the integral of a mean density over a measured area, was taken to calculate the amount in each sample according to the known standard values (Figure 1).

\section{Measurement of serum levels of HMGB1}

Approximately $25 \mathrm{ml}$ of whole blood was collected in nonheparinized tubes from patients. Within 4 hours of the collection, the blood was centrifuged at 3,000 rpm for 15 minutes and the serum fraction was aliquoted and stored at $-70^{\circ} \mathrm{C}$ in microfuge tubes until assayed. HMGB1 was measured by the commercially available Human HMGB1 ELISA Kit (USCN LIFE Science, Wuhan, China). Briefly, 100 $\mu \mathrm{l}$ of sample diluent was added to each well and then $10 \mu \mathrm{l}$ of standard, and sample or control was added to the well. The microtiter plates were incubated for $20-24$ hours at $37^{\circ} \mathrm{C}$. After washing, $100 \mu \mathrm{l} /$ well of biotinconjugated polyclonal antibody preparation specific for HMGB1 and avidin conjugated to horseradish peroxidase was added and the plates were incubated at room temperature for 2 hours. After washing, a 3, 3', 5,5 'tetra-methylbenzidine substrate solution was added to each well. Only those wells that contain HMGB1, biotin-conjugated antibody, and enzyme-conjugated avidin will exhibit a change in color. The enzyme-substrate reaction is terminated by the addition of a sulphuric acid solution and the color change is measured spectrophotometrically

A

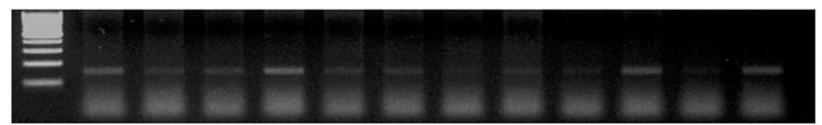

B

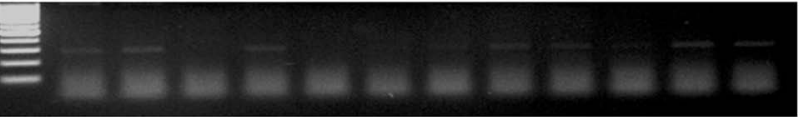

C

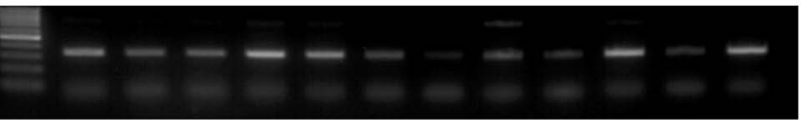

D

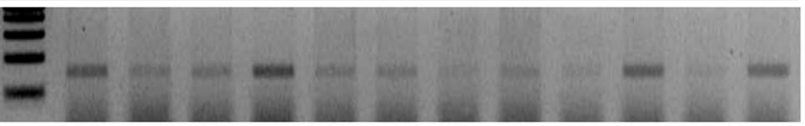

$\mathbf{E}$

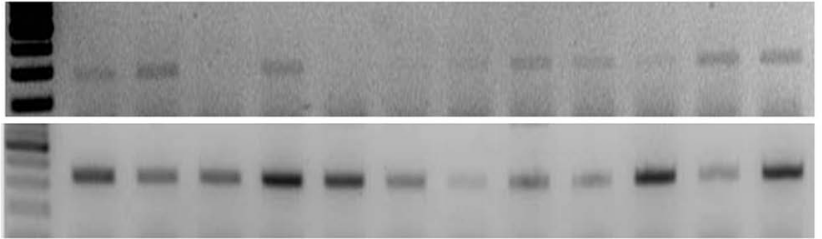

Figure 1. RT-PCR analysis of protein expression in epithelial ovarian cancer; (A) HMGB (150bp), (B) RAGE (100bp), and (C) $\beta$-actin (320bp); (D-F) Densitometry analysis of each band, (A), (B), (C). at a wavelength of $450 \mathrm{~nm} \pm 2 \mathrm{~nm}$. The concentration of HMGB1 in the samples is then determined by comparing the optical density of the samples to the standard curve.

\section{Statistical analysis}

All continuous data are expressed as mean \pm standard deviation, and categorical data are reported as an absolute number or percentage. Frequency distributions were compared using Chi-square test, and mean or median values were compared using Student's t- and MannWhitney U-tests. All the tests were to assess the null hypotheses that the patient characteristics and clinical outcomes were not different among groups. All calculated $\mathrm{P}$ values were 2 sided, and $\mathrm{P}<0.05$ was considered statistically significant. Data were analyzed using SAS/STAT software, version 9.4 (SAS Institute Inc., NC, USA).

\section{Results}

Overall, 78 patients were eligible for analysis; 45 with EOC and 21 with a benign ovary tumor, and 12 with normal ovarian tissue. The median age for patients with EOC was significantly higher compared to that among patients without cancer ( $52 v s .45$ years old, respectively, $\mathrm{P}=0.018$ ). However, the number of menopausal women did not differ between the EOC and non-cancer group. The clinicopathological characteristics of analyzed patients are shown in Table 1.

The expressions of HMGB1 and its receptor, RAGE, in EOC were tested by RT-PCR analysis. The mRNA levels of HMGB1 were higher in EOC compared to the non-cancer cohort $(0.94 v s .0 .90)$ and there was no statistically significant difference (Figure 2A). The median value of mRNA HMGB1 levels of cases with normal ovarian tissue, 0.90 , was estimated as a cut-off value. Similarly, there was no statistical significance between the EOC group and non-cancer group. The mRNA levels of RAGE did not differ between the EOC and non-cancer cohort (Figure 2B). As the median value of mRNA RAGE levels of cases with normal ovarian tissue, 0.01 , was estimated as a cut-off value, there was no statistical significance between EOC group and non-cancer group (Table 2). The serum levels of HMGB1 were evaluated between the groups. No significant differences were found between the EOC and non-cancer group ( $0.40 v s .0 .45 \mathrm{ng} / \mathrm{mL}, \mathrm{P}=0.106)$.

\section{Discussion}

Lotze and Tracey demonstrated that HMGB1 occupied a central role in mediating the local and systemic responses to necrotic cell death and cancer, invasion by pathogens, trauma and sepsis and it had differential tissue-specific activities [7]. Furthermore, the expression of HMGB1 has been strongly related to tumor growth and invasion. Taguchi et al. showed that HMGB1 induced several intracellular signaling pathways via binding to its receptor RAGE as an extracellular molecular. The co-localization of RAGE and HMGB1 indicated their potential contribution to cellular migration and tumor invasion, and the suppression of tumor growth and metastasis by blocking RAGEHMGB1 complex in mice had been reported [18].

In this study, we demonstrated that there was no statistical difference of mRNA levels of HMGB1 between the cancer and the non-cancer group. Although it may be controversial that HMGB1 is regarded as a significant factor in the development and progression of cancers, one common tumor-promoting mechanism may involve inflammation. Inflammatory conditions increase the risk of neoplasm and an inflammatory component is present also in the microenvironment of tumors that are not related to inflammation [19]. In the tumor microenvironment, inflammation could be related with 

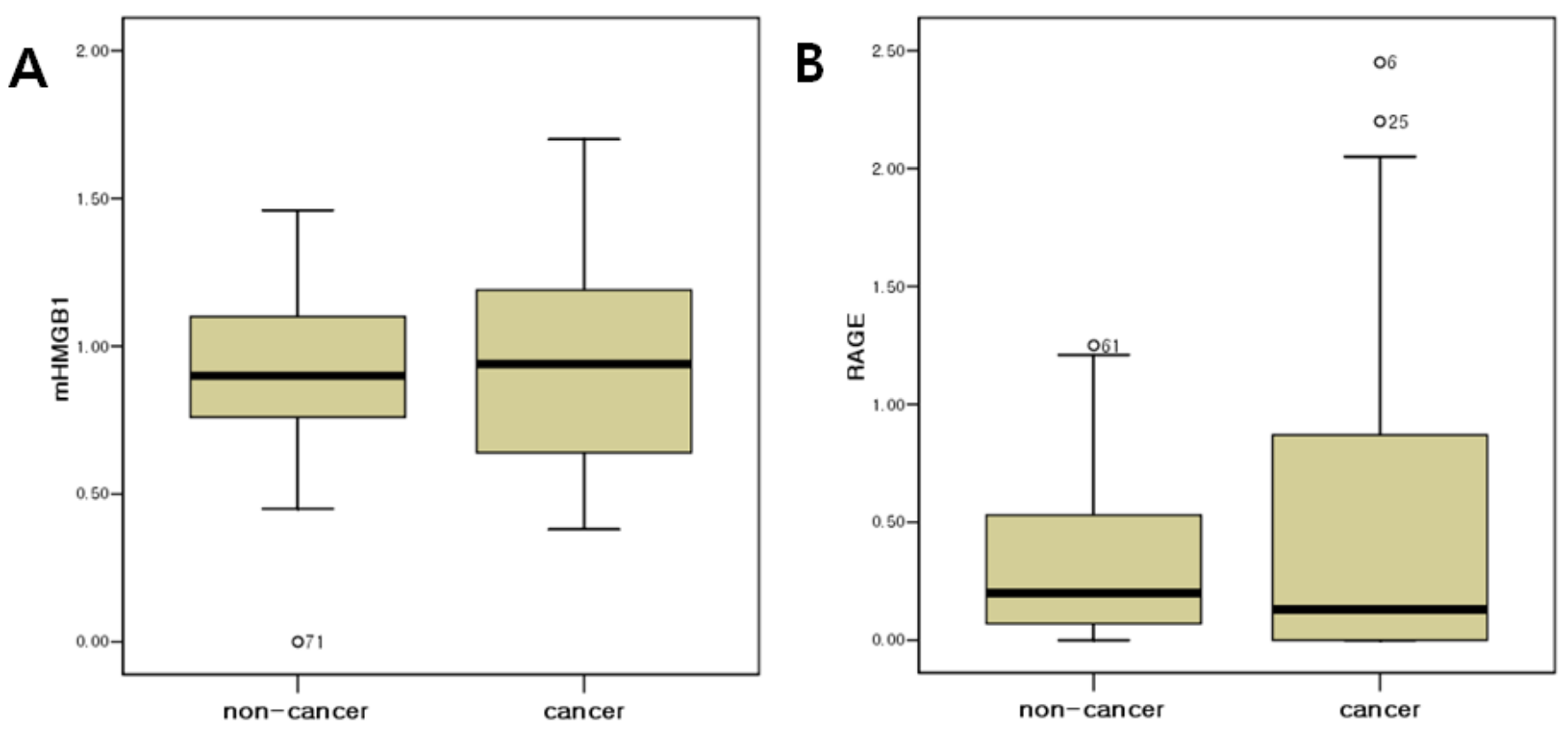

Figure 2. Comparison of the mRNA levels of (A) HMGB1 and (B) RAGE between the epithelial ovarian cancer and non-cancer group.

Table 1. Patient characteristics ( $\mathrm{n}=78)$.

\begin{tabular}{|c|c|c|c|}
\hline & Cancer $(n=45)$ & Non-cancer $(n=33)$ & \multirow{2}{*}{$P$ value } \\
\hline & \multicolumn{2}{|c|}{ Number of patients $(\%)$} & \\
\hline $\begin{array}{l}\text { Mean age (years, } \\
\text { SD) }\end{array}$ & $51.1(10.72)$ & $44.7(11.36)$ & 0.018 \\
\hline Menopause & $28(62.2)$ & $14(42.4)$ & 0.083 \\
\hline \multicolumn{4}{|l|}{ Performance status } \\
\hline 0 & $16(35.6)$ & & \\
\hline 1 & $24(53.3)$ & & \\
\hline 2 & $5(11.1)$ & & \\
\hline \multicolumn{4}{|l|}{ Histology } \\
\hline Serous & $37(82.2)$ & $2(6.1)$ & \\
\hline Mucinous & $4(8.9)$ & $2(6.1)$ & \\
\hline Clear cell & $3(6.7)$ & & \\
\hline Undifferentiated & $1(2.2)$ & & \\
\hline Teratoma & & $6(18.2)$ & \\
\hline Simple cyst & & $7(21.2)$ & \\
\hline Endometrioma & & $4(12.1)$ & \\
\hline Normal ovary & & $12(36.4)$ & \\
\hline \multicolumn{4}{|l|}{ Tumor grade } \\
\hline 1 & $12(26.7)$ & & \\
\hline 2 & $12(26.7)$ & & \\
\hline 3 & $21(46.6)$ & & \\
\hline \multicolumn{4}{|l|}{$\begin{array}{l}\text { Lymph node } \\
\text { metastases }\end{array}$} \\
\hline Negative & $29(64.4)$ & & \\
\hline Positive & $16(35.6)$ & & \\
\hline \multicolumn{4}{|l|}{ Tumor stage } \\
\hline I & $10(22.2)$ & & \\
\hline II & 0 & & \\
\hline III & $34(75.6)$ & & \\
\hline IV & $1(2.2)$ & & \\
\hline
\end{tabular}

\section{SD: Standard Deviation}

proliferation and survival of malignant cells, angiogenesis, metastasis, subversion of adaptive immunity, reduced response to hormones and chemotherapeutic agents. Recent efforts have shed new light on molecular and cellular pathways linking inflammation and cancer [20].
For the mRNA analysis, used tissues were not sampled from the tumor mass according to a consistent standard able to explain contained tumor percentage. In addition, the number of patients in the noncancer group ( $n=33)$, including benign ovarian tumors $(n=21)$, was small compared to the EOC group $(n=45)$. This number of patients would not have had the statistical power to definitely detect a difference in the mean value between the two groups.

A recent study showed that HMGB1 could be detected in the serum of cancer patients because it can be passively released from dying tumor cells, or actively released from immune cells into the extra-cellular space or serum [17]. In the present study, we quantified serum HMGB1 levels in patients with EOC, benign ovarian tumors, and normal ovarian tissue. However, the serum levels of HMGB1 were not significantly different between the EOC and non-cancer cohort. In addition, contrary to expectations, the mRNA RAGE levels did not differ significantly between the EOC and non-cancer cohort. Although HMGB1 and its receptor, RAGE, are expected to be elevated in almost all types of cancer, recent studies have revealed that this is not always true [21]. Especially for ovarian cancer, it is recognized that there are at least two different molecular pathways that lead to the development of ovarian cancer and that these result in tumors that have quite distinct biological behaviors and probably different cells of origin [22]. Kurman et al. demonstrated that ovarian cancers were divided into 2 groups, type I and type II. Type I tumors are slow growing, generally confined to the ovary at diagnosis, and develop from well-established precursor lesions that are termed borderline tumors [23]. Type I tumors include lowgrade micropapillary serous carcinoma, mucinous, endometrioid, and clear cell carcinomas. In contrast, type II tumors are rapidly growing, highly aggressive neoplasms, including high-grade serous carcinoma, malignant mixed müllerian tumor, and undifferentiated carcinomas. Most ovarian cancers that belong to the type II tumors have a high level of genetic instability [24]. Because of these heterologous patterns of ovarian cancer, serum CA125 assays and transvaginal ultrasound, which are most popularly used as screening modalities for EOC, have not been effective in detecting these tumors at the early stage. Similarly, the dubitable mRNA or serologic results of HMGB1 in our study can 
Table 2. The expression of mRNA levels of HMGB1 and RAGE among patients with epithelial ovarian cancer and no cancer.

\begin{tabular}{|c|c|c|c|}
\hline & Cancer $(\mathbf{n}=\mathbf{4 5})$ & Non-cancer $(\mathbf{n = 3 3})$ & P value \\
\hline $\begin{array}{c}\text { HMGB1 } \\
\text { (median, range) }\end{array}$ & $0.94(0.38-1.70)$ & $0.90(0-1.46)$ & 0.789 \\
\hline$\leq 0.90$ & 22 & 18 & 0.653 \\
\hline$>0.90$ & 23 & 15 & \\
\hline $\begin{array}{c}\text { RAGE } \\
\text { (median, range) }\end{array}$ & $0.13(0-2.45)$ & $0.20(0-1.25)$ & 0.636 \\
\hline$\leq 0.01$ & 22 & 8 & 0.053 \\
\hline$>0.01$ & 23 & 25 & \\
\hline
\end{tabular}

be explained with this characteristic of ovarian cancer. Therefore, individual studies of HMGB1 in each type of EOC and knowledge of the pathogenesis of various types of ovarian cancer are needed to have a more accurate understanding of HMGB1-related mechanisms in cancer development and progress. In conclusion, the expression of both HMGB1 and RAGE did not show significant differences in EOC group contrary to expectations as a promising biomarker for EOC. Further studies are needed to assess potential roles in EOC.

\section{Acknowledgments}

This study was supported by the Brain Korea (BK) 21 project for medical sciences, Yonsei University and by National Research Foundation of Korea Grant funded by the Korean Government (20090071158).

\section{References}

1. Siegel RL, Miller KD, Jemal A (2015) Cancer statistics, 2015. CA Cancer J Clin 65: 5-29. [Crossref]

2. Malkasian GD Jr, Knapp RC, Lavin PT, Zurawski VR Jr, Podratz KC, et al. (1988) Preoperative evaluation of serum CA 125 levels in premenopausal and postmenopausal patients with pelvic masses: discrimination of benign from malignant disease. $\mathrm{Am} \mathrm{J}$ Obstet Gynecol 159: 341-346. [Crossref]

3. Jacobs I, Bast RC Jr (1989) The CA 125 tumour-associated antigen: a review of the literature. Hum Reprod 4: 1-12. [Crossref]

4. Wang L, Kong B (2015) Analysis of the Association of Matrix Metalloproteinase-1 Gene Promoter (rs1799750) Polymorphism and Risk of Ovarian Cancer. Int J Gynecol Cancer 25: 961-967. [Crossref]

5. Kim JH, Skates SJ, Uede T, Wong KK, Schorge JO, et al. (2002) Osteopontin as a potential diagnostic biomarker for ovarian cancer. JAMA 287: 1671-1679. [Crossref]

6. Wilailak S, Chan KK, Chen CA, Nam JH, Ochiai K, et al. (2015) Distinguishing benign from malignant pelvic mass utilizing an algorithm with HE4, menopausal status, and ultrasound findings. J Gynecol Oncol 26: 46-53. [Crossref]

7. Lotze MT, Tracey KJ (2005) High-mobility group box 1 protein (HMGB1): nuclear weapon in the immune arsenal. Nat Rev Immunol 5: 331-342. [Crossref]

8. Mignogna MD, Fedele S, Lo Russo L, Lo Muzio L, Bucci E (2004) Immune activation and chronic inflammation as the cause of malignancy in oral lichen planus: is there any evidence? Oral oncol 40: 120-130. [Crossref]
9. Sims GP, Rowe DC, Rietdijk ST, Herbst R, Coyle AJ (2010) HMGB1 and RAGE in inflammation and cancer. Annu Rev Immunol 28: 367-388. [Crossref]

10. Schmidt AM, Vianna M, Gerlach M, Brett J, Ryan J, et al. (1992) Isolation and characterization of binding proteins for advanced glycosylation endproducts from lung tissue which are present on the endothelial cell surface. J Biol Chem 267: 14987 14997. [Crossref]

11. Hori O, Brett J, Slattery T, Cao R, Zhang J, et al. (1995) The receptor for advanced glycation endproducts (RAGE) is a cellular binding site for amphoterin: mediation of neurite outgrowth and coexpression of RAGE and amphoterin in the developing nervous system. J Biol Chem 270: 25752-25761. [Crossref]

12. Wautier JL, Zoukourian C, Chappey O, Wautier MP, Guillausseau PJ, et al. (1996) Receptor-mediated endothelial cell dysfunction in diabetic vasculopathy: soluble receptor for advanced glycation endproducts blocks hyperpermeability. J Clin Invest 97: 238- 243. [Crossref]

13. Flohr AM, Rogalla P, Meiboom M, Borrmann L, Krohn M, et al. (2001) Variation of HMGB1 expression in breast cancer. Anticancer Res 21: 3881-3885. [Crossref]

14. Kuniyasu H, Oue N, Wakikawa A, Shigeishi H, Matsutani N, et al. (2002) Expression of receptors for advanced glycation end-products (RAGE) is closely associated with the invasive and metastatic activity of gastric cancer. J Pathol 196: 163-170. [Crossref]

15. Kuniyasu H, Chihara Y, Kondo H, Ohmori H, Ukai R (2003) Amphoterin induction in prostatic stromal cells by androgen deprivation is associated with metastatic prostate cancer. Oncol Rep 10: 1863-1868. [Crossref]

16. Takada M, Hirata K, Ajiki T, Suzuki Y, Kuroda Y (2004) Expression of receptor for advanced glycation end products (RAGE) and MMP-9 in human pancreatic cancer cells. Hepatogastroenterology 51: 928-930. [Crossref]

17. Cheng BQ, Jia CQ, Liu CT, Lu XF, Zhong N, et al. (2008) Serum high mobility group box chromosomal protein 1 is associated with clinicopathologic features in patients with hepatocellular carcinoma. Dig Liver Dis 40: 446-452. [Crossref]

18. Taguchi A, Blood DC, del Toro G, Canet A, Lee DC, et al. (2000) Blockade of RAGEamphoterin signalling suppresses tumour growth and metastases. Nature 405: 354-360. [Crossref]

19. Colotta F, Allavena P, Sica A, Garlanda C, Mantovani A (2009) Cancer-related inflammation, the seventh hallmark of cancer: links to genetic instability. Carcinogenesis 30: 1073-1081. [Crossref]

20. Mantovani A, Allavena P, Sica A, Balkwill F (2008) Cancer-related inflammation. Nature 454: 436-444. [Crossref]

21. Bartling B, Hofmann HS, Weigle B, Silber RE, Simm A (2005) Down-regulation of the receptor for advanced glycation end-products (RAGE) supports non-small cell lung carcinoma. Carcinogenesis 26: 293-301. [Crossref]

22. Kurman RJ, Shih I (2008) Pathogenesis of ovarian cancer: lessons from morphology and molecular biology and their clinical implications. Int J Gynecol Pathol 27: 151160. [Crossref]

23. Gershenson DM, Sun CC, Lu KH, Coleman RL, Sood AK, et al. (2006) Clinical behavior of stage II-IV low-grade serous carcinoma of the ovary. Obstet Gynecol 108 361-368. [Crossref]

24. Shih IeM, Kurman RJ (2004) Ovarian tumorigenesis: a proposed model based on morphological and molecular genetic analysis. Am J Pathol 164: 1511-1518. [Crossref]

Copyright: (C2017 Paek J. This is an open-access article distributed under the terms of the Creative Commons Attribution License, which permits unrestricted use, distribution, and reproduction in any medium, provided the original author and source are credited. 